\title{
MODEL PORTOFOLIO OPTIMAL MARKOWITZ PADA SAHAM INDEKS LQ45 PERIODE JANUARI 2015 - JANUARI 2019
}

\author{
PUTRI, DODI DEVIANTO, YUDIANTRI ASDI \\ Program Studi S1 Matematika, \\ Fakultas Matematika dan Ilmu Pengetahuan Alam, Universitas Andalas, \\ Kampus UNAND Limau Manis Padang, Indonesia. \\ email : Putrisikumbang889@gmail.com,ddevianto@sci.unand.ac.id, \\ yudiantriasdi@sci.unand.ac.id
}

\begin{abstract}
Abstrak. Investasi saham merupakan trend yang sedang berkembang pesat di dunia perekonomian Indonesia. Dalam melakukan investasi, investor akan membentuk sebuah portofolio untuk memperoleh keuntungan yang maksimal. Portofolio optimal dapat dibentuk menggunakan model Markowitz. Model Markowitz berfokus untuk meminimalkan risiko tanpa mengubah nilai return yang akan diperoleh. Pada studi kasus data perusahaan yang terdaftar konsisten dalam Indeks LQ45 periode Januari 2015-Januari 2019, diperoleh portofolio optimal dengan nilai return ekspektasi sebesar 0.010984851 dan perolehan nilai risiko sebesar 0.030635422
\end{abstract}

Kata Kunci: Portofolio Optimal, Portofolio Markowitz

\section{Pendahuluan}

Dasar keputusan investasi terdiri dari tingkat return yang diharapkan, tingkat risiko serta hubungan antara return dan risiko. Agar mendapat nilai return ekspektasi yang maksimal, investor perlu membentuk portofolio yang efisien. Menurut [11], biasanya investor ingin memaksimalkan nilai return ekspektasi yang diperoleh dengan mengambil nilai risiko terendah dari kedua situasi tersebut.

Pada sekumpulan portofolio efisien yang telah dibentuk, investor dapat memilih portofolio yang sesuai dengan preferensinya. Portofolio terpilih ini dalam [11] disebut portofolio optimal. Dalam pemilihan portofolio yang optimal ada beberapa model yang dapat digunakan, salah satu model terbaik adalah model Markowitz. Karakteristik dari model ini pada [6] adalah mendiversifikasikan risiko sehingga memperoleh nilai risiko yang paling minimum. Model Markowitz sendiri adalah pengembangan dari konsep mean-variance optimization. Konsep mean-variance memiliki tingkat aplikabilitas yang luas. Penelitian sebelumnya yang menggunakan

${ }^{*}$ penulis korespondensi 
konsep mean-variance adalah penelitian oleh Aydin Ulucan (2007). Penelitian ini menunjukkan bahwa konsep portofolio Markowitz dengan model mean-variance merupakan model terbaik yang dapat digunakan dalam studi kasus harga saham bulanan ISE National 100-Price Index dan FTSE/ASE Mid Cap.40-Price Index. Meskipun begitu, seringkali terdapat kendala dalam menggunakan model ini seperti kehilangan nilai dalam beberapa penerapan pada portofolio yang optimal, serta kesulitan yang ditimbulkan pada banyaknya data input yang harus dimasukkan guna memperoleh portofolio yang optimal.

Pada kali ini akan dilakukan perhitungan portofolio yang optimal dengan menggunakan portofolio optimal model Markowitz untuk data saham-saham perusahaan yang terdaftar secara konsisten dalam indeks LQ45 selama periode Januari 2015Januari 2019.

\section{Landasan Teori}

\subsection{Teori Portofolio}

Portofolio adalah sekumpulan dari instrumen investasi yang dibentuk untuk mengurangi risiko yang mungkin terjadi dalam investasi. Menggambarkan bahwa sebuah perusahaan merupakan salah satu atau bagian dari sebuah investasi tertentu. Portofolio biasanya terdiri atas portofolio efisien dan portofolio optimal.

Portofolio efisien adalah portofolio yang memberikan nilai return ekspektasi terbesar dengan tingkat risiko yang sama atau sebaliknya. Portofolio-portofolio efisien adalah portofolio-portofolio yang baik, namun bukan yang terbaik karena hanya ada satu portofolio terbaik yaitu portofolio optimal. Portofolio optimal merupakan portofolio terbaik yang dipilih seorang investor dari sekian banyak pilihan portofolio yang tersedia dalam sekumpulan portofolio efisien.

\subsubsection{Return Portofolio}

Return portofolio merupakan rata-rata tertimbang dari seluruh return sekuritas tunggal. Return portofolio terdiri atas return realisasi dan return ekspektasi. Return realisasi portofolio dinyatakan sebagai berikut.

$$
R_{p}=\sum_{i=1}^{n} w_{i} R_{i}
$$

Sedangkan return ekspektasi portofolio dapat dinyatakan sebagai berikut.

$$
E\left(R_{p}\right)=\sum_{i=1}^{n} w_{i} E\left(R_{i}\right)
$$

\subsubsection{Risiko Portofolio}

Risiko portofolio adalah varian return sekuritas-sekuritas yang membentuk portofolio tersebut. Persamaan risiko portofolio dapat ditulis sebagai berikut.

$$
\sigma_{p}^{2}=E\left[R_{p}-E\left(R_{p}\right)\right]^{2}
$$


Untuk portofolio dengan banyak aktiva (biasanya terdiri dari $n$ sekuritas dengan $n \geq 2$ ), maka dapat ditulis persamaan sebagai berikut.

$$
\sigma_{p}^{2}=\sum_{i=1}^{n} w_{i}^{2} \sigma_{i}^{2}+2 \sum_{i=1}^{n-1} \sum_{j=i+1}^{n} w_{i} w_{j} \sigma_{i j}
$$

\subsection{Portofolio Markowitz}

Model Markowitz mengidentifikasikan portofolio-portofolio yang berada di efficient set. Teori portofolio dengan model Markowitz dalam [6] didasari oleh asumsi-asumsi sebagai berikut.

(1) Periode investasi tunggal

(2) Tidak ada biaya transaksi

(3) Preferensi investor hanya berdasar pada return yang diharapkan dan risiko

(4) Tidak ada pinjaman dan simpanan bebas risiko

Model penyelesaian optimasi dari portofolio optimal model Markowitz ini dapat ditulis sebagai berikut [6].

Fungsi Objektif:

$$
\operatorname{Min}\left(\sigma^{2}\right)=\operatorname{Min} \sum_{i=1}^{n} w_{i}^{2} \sigma_{i}^{2}+\sum_{i=1}^{n} \sum_{j=1}^{n} w_{i} w_{j} \sigma_{i j}, \quad i \neq j
$$

dengan kendala-kendala :

(1) $\sum_{i=1}^{n} w_{i}=1$

(2) $w_{i} \geq 0$ untuk $i=1, \ldots, n$

(3) $\sum_{i=1}^{n} w_{i} R_{i}=R_{p}$

dimana $w_{i}$ adalah proporsi dana pada sekuritas ke- $i, w_{j}$ adalah proporsi dana pada sekuritas ke- $j, \sigma_{i}^{2}$ adalah varian dari sekuritas ke- $i \sigma_{i j}$ adalah kovarian antara sekuritas ke- $i$ dan sekuritas ke- $j, \sigma^{2}$ adalah varian dari portofolio, $R_{p}$ adalah return portofolio yang diharapkan, $R_{i}$ adalah return sekuritas ke- $i$ yang diharapkan dan $n$ adalah banyak observasi sekuritas.

\section{Pembahasan}

\subsection{Return Ekspektasi dan Risiko Portofolio}

Berikut perusahaan terpilih dengan nilai return ekspektasi dan risiko saham dalam pembentukan portofolio optimal Markowitz. 


\begin{tabular}{|c|c|c|}
\hline Kode Aset & Return Ekspektasi $\left(E\left(R_{i}\right)\right)$ & Risiko $\left(\sigma_{i}\right)$ \\
\hline ADRO & 0.013235228 & 0.114759688 \\
AKRA & 0.005563415 & 0.080670684 \\
ASII & 0.0038167 & 0.066578642 \\
BBCA & 0.016326134 & 0.047502785 \\
BBNI & 0.011643557 & 0.08653788 \\
BBRI & 0.013201101 & 0.073773128 \\
BMRI & 0.026623867 & 0.103211359 \\
GGRM & 0.008191197 & 0.060509561 \\
ICBP & 0.009758808 & 0.064490629 \\
INCO & 0.009694742 & 0.053281076 \\
INDF & 0.015299454 & 0.164564934 \\
INTP & 0.003021173 & 0.070977247 \\
\hline
\end{tabular}

Sambungan Tabel 3.1

\begin{tabular}{|c|c|c|}
\hline Kode Aset & Return Ekspektasi $\left(E\left(R_{i}\right)\right)$ & Risiko $\left(\sigma_{i}\right)$ \\
\hline JSMR & 0.001708299 & 0.103033036 \\
PTBA & 0.022774386 & 0.138920785 \\
SMGR & 0.00137433 & 0.094649702 \\
TLKM & 0.008380549 & 0.057258157 \\
UNTR & 0.010662797 & 0.079233197 \\
UNVR & 0.008546943 & 0.057276508 \\
WSKT & 0.008055248 & 0.096367316 \\
\hline
\end{tabular}

\subsection{Portofolio Markowitz}

Terlebih dahulu akan ditentukan portofolio efisien dengan melakukan perhitungan return ekspektasi dan risiko portofolio. Perolehan return ekspektasi dan risiko pada portofolio efisien menggunakan Persamaan (2.1) dan Persamaan (2.2) sebagai berikut.

Dengan kurva portofolio efisien yang diperoleh sebagai berikut.

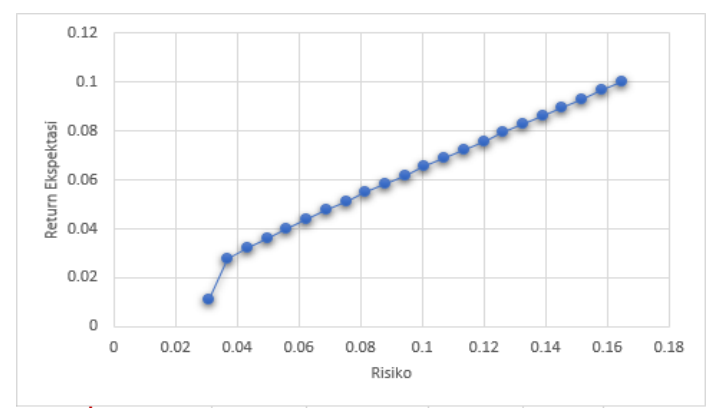

Gambar 1. Portofolio Efisien yang Terbentuk dari 19 Saham 


\begin{tabular}{|c|c|c|}
\hline No Port. & Risiko $\left(\sigma_{i}\right)$ & Return Ekspektasi $\left(E\left(R_{i}\right)\right)$ \\
\hline 1 & 0.164564934 & 0.09993304 \\
2 & 0.158187338 & 0.096500961 \\
3 & 0.151809742 & 0.093065238 \\
4 & 0.145432146 & 0.089625379 \\
5 & 0.13905455 & 0.086180796 \\
6 & 0.132676955 & 0.082730785 \\
7 & 0.126299359 & 0.079274491 \\
8 & 0.119921763 & 0.075810867 \\
9 & 0.113544167 & 0.072338621 \\
10 & 0.107166571 & 0.068856128 \\
11 & 0.100788976 & 0.065361324 \\
12 & 0.09441138 & 0.06185154 \\
13 & 0.088033784 & 0.058323255 \\
14 & 0.081656188 & 0.054771725 \\
15 & 0.075278592 & 0.051190376 \\
16 & 0.068900997 & 0.047569804 \\
17 & 0.062523401 & 0.043895991 \\
18 & 0.056145805 & 0.040146918 \\
19 & 0.049768209 & 0.03628545 \\
20 & 0.043390613 & 0.032242207 \\
21 & 0.037013018 & 0.027864404 \\
22 & 0.030635422 & 0.010984851 \\
\hline
\end{tabular}

Untuk memperoleh nilai return portofolio yang diharapkan serta risikonya maka akan dilakukan perhitungan diversifikasi demi mendapat proporsi dengan nilai risiko seminimum mungkin. Perhitungan mula-mula adalah dengan membagi sama rata proporsi untuk setiap aset kemudian melakukan perhitungan risiko portofolio menggunakan Persamaan (2.3). Selanjutnya dilakukan proses diversifikasi risiko hingga memperoleh nilai risiko paling optimal sekaligus proporsi 19 aset portofolio optimal. Tabel berikut merupakan proporsi aset portofolio optimal yang sudah didiversifikasi.

\begin{tabular}{|c|c|c|c|c|c|}
\hline No. & Kode Aset & Proporsi & No. & Kode Aset & Proporsi \\
\hline 1 & ADRO & $0 \%$ & 11 & INCO & $4.22 \%$ \\
2 & AKRA & $1.7 \%$ & 12 & INDF & $0 \%$ \\
3 & ASII & $0 \%$ & 13 & INTP & $0 \%$ \\
4 & BBCA & $22.21 \%$ & 14 & PTBA & $0 \%$ \\
5 & BBNI & $0 \%$ & 15 & SMGR & $0 \%$ \\
6 & BBRI & $0 \%$ & 16 & TLKM & $21.92 \%$ \\
7 & BBTN & $0 \%$ & 17 & UNTR & $11.65 \%$ \\
8 & BMRI & $0 \%$ & 18 & UNVR & $15.98 \%$ \\
9 & GGRM & $16.08 \%$ & 19 & WSKT & $0 \%$ \\
10 & ICBP & $6.23 \%$ & & & \\
\hline & Total & & & & $100 \%$ \\
\hline
\end{tabular}

Portofolio optimal diperoleh dari kurva portofolio efisien untuk nilai risiko terkecil yaitu $\sigma_{p}=0.030635422$ dan nilai return ekspektasi portofolio optimal yang di- 
harapkan, yaitu $E\left(R_{p}\right)=0.010984851$.

\section{Kesimpulan}

Pada studi kasus ini, perhitungan menggunakan model Markowitz memperoleh nilai return ekspektasi optimal sebesar 0.010984851 dan nilai risiko yang telah didiversifikasi sebesar 0.030635422. Portofolio dibentuk dari 19 saham perusahaan yang terdaftar konsisten pada Indeks LQ45 dengan proporsi masing-masing saham yang telah ditentukan.

\section{Daftar Pustaka}

[1] Ahmad, Kamaruddin. 1996. Dasar-Dasar Manajemen Investasi. Rineka Cipta, Jakarta

[2] Bain, L.J. and M. Engelhardt. 1992. Introduction to Probability and Mathematical Statistics Second Edition. Duxbury Press, California

[3] Bank Indonesia. Tanpa Tahun. BI Rate. http://www.bi.go.id, tanggal akses pada 31 Agustus 2019.

[4] Bursa Efek Indonesia. Tanpa Tahun. Saham. http://www.idx.co.id, tanggal akses pada 16 Agustus 2019.

[5] Google. Tanpa Tahun. Saham. https://www.google.com/finance, tanggal akses pada 16 Agustus 2019

[6] Hartono, J. 2017. Teori Portofolio dan Analisis Investasi. Edisi Kesebelas. Universitas Gadjah Mada, Yogyakarta

[7] Hartono, J. 2014. Teori dan Praktik Portofolio dengan Excel. Salemba Empat, Jakarta

[8] Husnan, Suad. 1998. Dasar-Dasar Teori Portofolio dan Analisis Sekuritas. Edisi Ketiga. AMP YKPN, Yogyakarta

[9] Johnson, R.A and D.W. Wichern. 2007. Applied Multivariate Statistical Analysis. Sixth Edition. Pearson Education, Inc, United State of America

[10] Suhartono and Fadlillah Qudsi. 2009. Portofolio Investasi dan Bursa Efek (Pendekatan Teori dan Praktik). Sekolah Tinggi Ilmu Manajemen YKPN, Yogyakarta

[11] Tandelilin, E. 2001. Analisis Investasi dan Manajemen Portofolio. Edisi Pertama. Universitas Gadjah Mada, Yogyakarta

[12] Tandelilin, E. 2012. Manajemen Investasi. Universitas Terbuka, Yog-yakarta 